\title{
A Case of Lung Squamous Cell Carcinoma Mimicking Benign Solitary Cyst
}

Lung cancer with cyst formation is a rare entity. We report a 63-year-old man who underwent surgical treatment of primary lung cancer, which mimics benign solitary cyst. We incidentally found his pulmonary cyst by a low dose chest tomography and followed up for 2 years. Rapid growth of cyst and focal wall thickening evoke us to have a suspicion of its malignancy. Left lower lobectomy via video-assisted thoracoscopic surgery was performed without any preoperative pathologic confirmation. The postoperative pathological finding revealed squamous cell carcinoma with carcinoma in situ on the cyst wall. We emphasize the need for physicians to be aware of the potential of lung cancer in patients with growing pulmonary cyst. (J Lung Cancer 2012;11(2):108-110)

Key Words: Lung neoplasms, Cysts, Squamous cell carcinoma

\author{
Ji Young Park, M.D., ${ }^{1,2}$ \\ Taehoon Lee, M.D. ${ }^{1,2}$ \\ Hong Yeul Lee, M.D. ${ }^{1,2}$ \\ Hyo-Jeong Lim, M.D. ${ }^{1,2}$ \\ Jong Sun Park, M.D., Ph.D. ${ }^{1,2}$ \\ Young-Jae Cho, M.D. ${ }^{1,2}$ \\ Ho II Yoon, M.D., Ph.D. ${ }^{1,2}$ \\ Jae Ho Lee, M.D., Ph.D., \\ Kyung Won Lee, M.D., Ph.D. ${ }^{3}$ \\ Bo Seong Kim, M.D. ${ }^{4}$ \\ Jin-Haeng Chung, M.D., Ph.D. ${ }^{4}$ \\ Kwhanmien Kim, M.D., Ph.D. ${ }^{5}$ \\ and Choon-Taek Lee, M.D., Ph.D. ${ }^{1,2}$ \\ ${ }^{1}$ Division of Pulmonary and Critical \\ Care Medicine, Department of Internal \\ Medicine and Lung Institute, Seoul \\ National University College of Medi- \\ cine, Seoul, Departments of ${ }^{2}$ Internal \\ Medicine, ${ }^{3}$ Radiology, ${ }^{4}$ Pathology, and \\ ${ }^{5}$ Thoracic and Cardiovascular Sur- \\ gery, Seoul National University Bun- \\ dang Hospital, Seoul National Univer- \\ sity College of Medicine, Seongnam, \\ Korea
}

Received: November 28, 2012 Accepted: November 30, 2012

\section{Address for correspondence} Choon-Taek Lee, M.D., Ph.D.

Department of Internal Medicine, Seoul National University Bundang Hospital, Seoul National University College of Medicine, 82, Gumi-ro, 173beon-gil, Bundang-gu, Seongnam 463-707, Korea

Tel: 82-31-787-7002

Fax: 82-31-787-4052

E-mail: ctlee@snu.ac.kr
단일 폐낭종(pulmonary cyst)은 일상 진료에서 드물지 않게 볼 수 있다. 대개의 경우 양성이며 폐기종에 의한 것이 흔하 다. 반면 낭종의 얇은 벽에서 발견된 폐암은 매우 드물다 (1). 이전 증례들에서, 낭종이 선천성 낭종인지 후천적으로 발생한 것인지는 명확하지 않으며 낭종이 폐암을 유발했는 지 아니면 폐암이 낭종의 형태로 발생한 것인지 구분하기 는 어렵다(2). 본 증례는 후천적으로 새롭게 발생한 낭종이
서서히 커지면서 발견된 폐암으로 그 진행 경과와 함께 치 료 결과를 보고하고자 한다.

\section{중 례}

63세 남자환자가 3 개월 이상 지속되는 기침으로 개인 의 원에서 치료하였지만, 호전이 없어 내원하였다. 과거 특이 
병력은 없었지만 80 갑년의 흡연자였다. 신체 검진에서 특 이 소견은 없었다. 말초 혈액검사, 전해질 검사, 생화학적 검사 및 심전도 검사에서 특이 소견은 없었다. 처음 내원 시 단순 흉부 방사선 사진에서 이상 소견이 없었지만, 저선 량 흉부 컴퓨터단층촬영(computed tomography, CT)에서는 양측 폐에 폐기종이 있었으며 좌하엽 흉막 아래쪽으로 직 경 $12 \mathrm{~mm}$, 벽두께 $1 \mathrm{~mm}$ 의 단일 낭종이 보여 경과를 관찰하 기로 하였다(Fig. 1A). 의료진이 금연을 권고하였지만 환자 는 흡연을 지속하였다. 1 년 후에 흉부 CT를 다시 실시하였
고 직경이 $26 \mathrm{~mm}$ 로 커졌으며 벽 두께가 $1.8 \mathrm{~mm}$ 로 두꺼워 진 부분이 보였다(Fig. 1B). 병변이 이전보다 진행하여 3 개 월 후에 흉부 $\mathrm{CT}$ 를 추적 검사하였지만, 변화가 없어 다시 1 년간 경과를 관찰하였다. 마지막으로 실시한 흉부 CT에서 크기는 $38 \mathrm{~mm}$ 로 더욱 커졌으며 두꺼워진 벽 한쪽에서 6 $\mathrm{mm}$ 크기의 결절이 발생하였다(Fig. 1C). 경과 관찰 중에 종 격동 임파선 증대는 관찰되지 않았다. 폐암이 의심되어 F-18 fludeoxyglucose-positron emission tomography/computed tomography를 실시하였고 결절을 동반한 낭종 부위에서 중
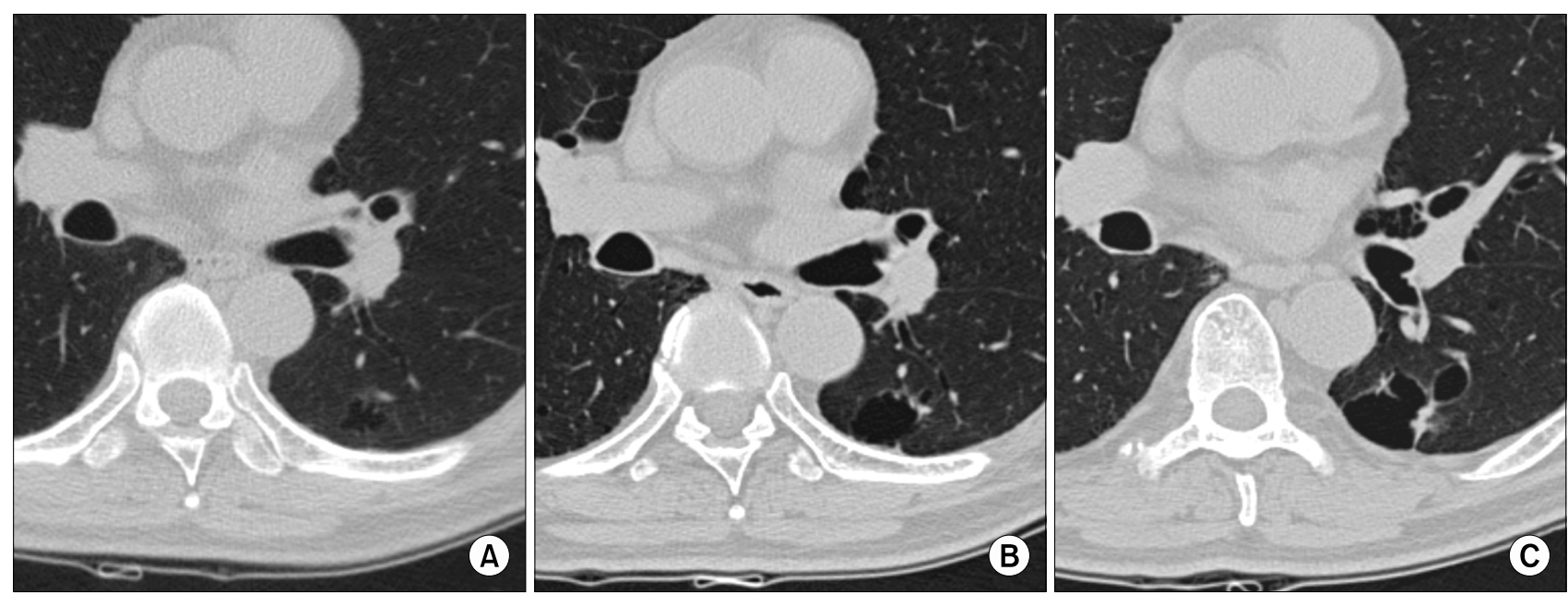

Fig. 1. The initial chest computed tomography (CT) scan showed a thin-walled cystic lesion in the left lower lobe. The cystic lesion had grown up during follow-up duration. After two years, the chest CT scan showed newly developed eccentric wall thickening and part solid component on the cyst (A, initial CT; B, after one year; C, after two years).
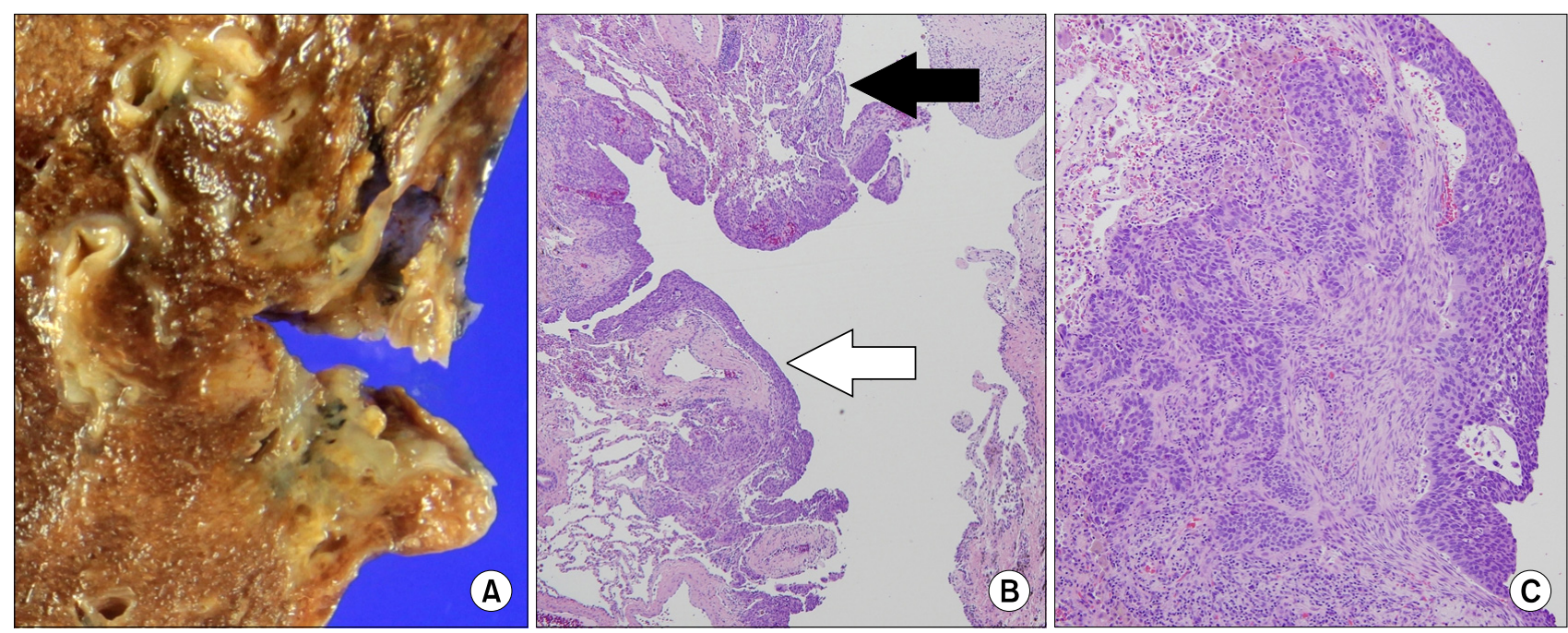

Fig. 2. (A) Gross appearance of resected specimen. Cystic lesion with irregular border was found. (B) Pathologic finding showed a squamous cell carcinoma that focally invaded the lung parenchyma (black arrow). Those were surrounded by carcinoma in situ on the cyst wall (white arrow) (H\&E, $\times 40)$. (C) Tumor cells showed hyperchromatic nuclei and intercellular bridge, characteristics of squamous cell carcinoma $(\mathrm{H} \& \mathrm{E}, \times 100)$. 
등도 당대사 항진(maximal standardized uptake value [SUV $\max =3.1$ )을 관찰할 수 있었다. 좌측 폐엽사이 임파선(interlobar lymph node)에서 당대사 항진(SUV max=3.2)이 보였 지만 종격동 임파선에서 당대사 항진은 보이지 않았다. 낭 종에 있는 매우 작은 결절이라서 세침흡입생검술은 시행하 지 않고 흉강경 수술을 통하여 좌하엽 절제술과 종격동 임 파선 절제술을 시행하였다(Fig. 2A).

조직 병리 결과에서 낭종의 결절 부위에서 중등도 분화 도의 편평세포암이 폐실질로 침습(invasion)하는 소견을 보 였으며 그 주변의 낭종의 벽부위에서 제자리암종(carcinoma in situ)의 형태로 관찰되었다(Fig. 2B). 고배율에서 세포사이 결합체(intercellular bridge) 등이 보이며 편평상피세포암의 소견을 보이고 있었다(Fig. 2C). 반면에 낭종의 다른 부분에 서는 편평상피화생(squamous metaplasia) 또는 이형성 세포 (dysplasia)가 포함된 섬유화된 낭종벽을 관찰할 수 있었다. 임파선 전이는 관찰되지 않았다.

\section{고 찰}

Chronic obstructive pulmonary disease (COPD)와 관련된 폐 기종성 공기집(bullous emphysema)은 폐암의 위험인자로 비 교적 잘 알려져 있다(3). 폐기종이 없는 폐 공기집(bullous lung disease without emphysema)에서도 폐암 발생한다는 보 고들이 있었으며(2) 발생학적 기형인 기관지기원 낭종 (bronchogenic cyst)에서도 악성 종양이 발생하는 것이 보고 되고 있다(4). 반면 단일 폐낭종은 일반적으로 양성으로 평 가되며 이와 관련되어 폐암이 발생한 경우는 몇몇 증례 보 고가 전부이다(1).

이런 낭성 폐 질환(cystic airspace)과 동반되어 발생하는 폐암의 병리 기전에 대한 몇 가지 가설들이 있다. 우선 종양 이 먼저 발생하고 이후 낭성 변화를 했다는 가설에는 종말 세기관지(terminal bronchioles) 부위에서 종양의 진행으로 인해 체크 밸브 폐쇄(check valve obstruction)가 생기며 이것 이 낭성 폐 질환을 유발한다는 것이 있으며(5), 종양세포로 인해 조직 견고함이 떨어져 주변 폐조직의 탄성력을 견디 지 못하고 낭성 변화를 하며 커진다는 가설도 있다(1). 반대 로 폐 공기집과 기관지기원 낭종 같이 이미 존재하는 낭성 폐 질환에서 종양이 발생한다는 가설에는 종양 유발 물질 등이 환기되어 배출되지 못하고 낭종 안에 침착되어 주변 세포의 이형성(metaplasia)을 조장하여 악성으로 진행한다 는 것이 있다(6). 반면에 공동성 종양(cavitary cancer)의 발생 기전은 종양의 중심부가 허혈성 괴사와 함께 녹아 기관지 로 배출되고 주변부에 남겨진 두꺼운 벽이 공동(cavity)을
형성하는 것으로서 낭종의 발생 기전과는 다르다.

본 증례의 경우 처음 낭종의 벽이 $1 \mathrm{~mm}$ 로 매우 얇고 균 일하여 암의 가능성을 의심할 수 없었으나 2 년에 걸쳐 비교 적 빨리 벽이 두꺼워지며 낭종의 크기가 커졌으며 이후 폐 암을 의심할 만한 결절이 형성되었다. 이처럼 종양이 분명 해지기 이전부터 낭종이 있었지만 이 사실 자체로는 낭종 이 폐암 발병에 선행했다는 근거로는 충분하지 않다. 조직 검사에서 국소 결절 부분에서만 악성세포가 관찰된 것이 아니라 비교적 넓은 부위에서 제자리암종의 형태로 관찰되 었기 때문에 CT에서 보이지 않을 정도로 작은 부분에서 이 미 악성 종양이 발생하였고 이것으로부터 낭종이 발생했을 가능성을 높아 보인다.

폐기종성 공기집에서 발생하는 폐암의 형태적 특징은 공 기집 주변으로 염증성 섬유화 반응처럼 벽이 두꺼워져 띠 모양(band-like)의 형태를 보이기도 하고 폐기종 사이의 정 상 폐 사이로 진행하기도 하여 일반적인 폐암과는 다른 형 태를 보이게 된다(7). 이와 유사하게 본 증례와 함께 이전에 보고된 증례에서도 낭종이 커지면서 벽이 두꺼워지는 소견 을 보였다(1).

결론적으로 크기가 커지고 있는 낭성 폐 질환은 영상학 적으로 양성처럼 보일지라도 세밀한 경과 관찰이 필요하며 미세한 벽 두께 증가의 소견도 수술적 치료를 선택하는데 결정적인 단서가 될 수 있겠다.

\section{REFERENCES}

1. Iwata T, Nishiyama N, Nagano K, et al. Squamous cell carcinoma presenting as a solitary growing cyst in lung: a diagnostic pitfall in daily clinical practice. Ann Thorac Cardiovasc Surg 2009;15:174-177.

2. Hirai S, Hamanaka Y, Mitsui N, Morifuji K, Sutoh M. Primary lung cancer arising from the wall of a giant bulla. Ann Thorac Cardiovasc Surg 2005;11:109-113.

3. Wilson DO, Weissfeld JL, Balkan A, et al. Association of radiographic emphysema and airflow obstruction with lung cancer. Am J Respir Crit Care Med 2008;178:738-744.

4. Jakopovic M, Slobodnjak Z, Krizanac S, Samarzija M. Large cell carcinoma arising in bronchogenic cyst. J Thorac Cardiovasc Surg 2005;130:610-612.

5. Farooqi AO, Cham M, Zhang L, et al. Lung cancer associated with cystic airspaces. AJR Am J Roentgenol 2012;199:781786.

6. Stoloff IL, Kanofsky P, Magilner L. The risk of lung cancer in males with bullous disease of the lung. Arch Environ Health 1971;22:163-167.

7. Takahashi M, Fukuoka J, Nitta N, et al. Imaging of pulmonary emphysema: a pictorial review. Int $\mathrm{J}$ Chron Obstruct Pulmon Dis 2008;3:193-204. 